\title{
Literasi informasi masyarakat Desa Paseban, Kecamatan Kencong, Kabupaten Jember melalui budaya 'marung'
}

\author{
Anita Tri Widiyawati \\ Program Studi Ilmu Perpustakaan, Universitas Brawijaya \\ Jl. M.T. Haryono No.163, Ketawanggede, Malang, Jawa Timur, Indonesia 65145 \\ E-mail: anitatriw@ub.ac.id
}

Received: December 2018; Accepted: May 2019; Published: June 2019

\begin{abstract}
The 'marung' culture is a custom of the people of Paseban village. The 'marung' activity is a means to relax after work, ward off feelings of loneliness by meeting neighbors, and sharing information. This becomes a potential for information literacy. The purpose of this study was to describe and analyze the factors underlying the formation of 'marung' culture and information literacy. The research method used qualitative research method. The data collection technique used was observation, interviews, and documentation. Data analysis steps in this study were (1) condensation of data, (2) presentation of data, and (3) drawing conclusions and verification. The data credibility test used: source triangulation, technique triangulation, and time triangulation. The result of this study showed 'marung' culture was formed based on the history of the village community to set strategies of defending themselves from Dutch colonialism by creating 'cangkrukan'/gathering habits. After the Dutch colonial period ended, this 'cangkrukan' habit became attached to the village community. The 'warung' was considered the most strategic place for 'cangkrukan'. This place can accommodate all people from various backgrounds to chat, have fun, establish 'silaturahmi'/hospitality, relax from daily activities, and get the information needed. 'Marung' culture fulfills four cultural systems, namely: culture, social, personality, and organism. 'Marung' culture is very closely related to information literacy and Hubermas' theory of public space. The Paseban village community has implemented the IFLA information literacy standard in supporting its work, from the access, evaluation, to usage stages.
\end{abstract}

Keywords: Information literacy; Marung culture; Village community of Paseban Village; Jember Regency

\begin{abstract}
Abstrak
Budaya marung adalah kebiasaan masyarakat Desa Paseban. Kegiatan marung merupakan sarana untuk melepas lelah setelah bekerja, menepis rasa kesepian karena bertemu dengan tetangga, serta berbagi informasi. Hal ini menjadi potensi adanya kegiatan literasi informasi. Tujuan penelitian ini adalah untuk mendeskripsikan dan menganalisis faktor yang melatarbelakangi terbentuknya budaya "marung" serta literasi informasinya. Metode penelitian yang digunakan adalah metode penelitian kualitatif. Teknik pengumpulan data yang digunakan, adalah: observasi, wawancara, dan dokumentasi. Langkah-langkah analisis data pada penelitian ini, yaitu: (1) kondensasi data, (2) penyajian data, serta (3) penarikan kesimpulan dan verifikasi. Uji kredibilitas data yang digunakan, yakni: triangulasi sumber, triangulasi teknik, dan triangulasi waktu. Hasil dari penelitian ini adalah budaya marung terbentuk dilatarbelakangi oleh sejarah masyarakat desa untuk mengatur strategi mempertahan diri dari penjajahan Belanda dengan menghasilkan kebiasaan cangkrukan/berkumpul. Setelah masa penjajahan Belanda berakhir, kebiasaan cangkrukan ini menjadi melekat pada masyarakat desa. Warung dianggap tempat yang paling strategis untuk cangkrukan. Di mana tempat ini bisa menampung semua masyarakat dari berbagai latar belakang untuk sekadar berbincang, bersenda gurau, menjalin silaturahmi, melepas lelah dari kegiatan sehari-hari, dan mendapat informasi yang dibutuhkan. Budaya marung memenuhi empat sistem budaya, yakni: budaya, sosial, kepribadian, dan organisme. Budaya marung sangat erat kaitannya dengan literasi informasi dan teori Hubermas tentang ruang publik. Masyarakat Desa Paseban secara sederhana telah menerapkan standar literasi informasi IFLA dalam mendukung pekerjaannya, dari tahap akses, evaluasi, sampai penggunaan.
\end{abstract}

Kata Kunci: Literasi informasi; Budaya marung; Masyarakat Desa Paseban; Kabupaten Jember 


\section{PENDAHULUAN}

Desa Paseban merupakan salah satu desa yang mempunyai potensi tinggi di Kabupaten Jember. Wilayahnya yang dekat dengan pantai merupakan kelebihan tersendiri yang dapat dijadikan sebagai sumber destinasi wisata dan juga sebagai sumber produksi ikan laut. Selain itu, pada dasarnya Desa Paseban mempunyai potensi yang sangat tinggi di bidang pertanian/sawah, ladang/tegalan, serta perikanan darat/tawar. Masyarakat menanam berbagai jenis tanaman yang bervariasi di bidang pertanian/sawah dan ladang/tegalan, mulai dari palawija sampai buah, bahkan umbi-umbian. Adapun dari bidang perikanan, untuk perikanan air tawar banyak masyarakat yang membuat tambak, baik tambak di rumah maupun tambak yang dibangun di area dekat persawahan. Adapun produk perikanan air tawar, antara lain: gurami, lele, mujair, dan banyak lagi. Terdapat pula potensi perikanan air payau.

Kebiasaan unik dari masyarakat Desa Paseban adalah budaya 'marung'. Marung bagi masyarakat Desa Paseban adalah kebutuhan yang sangat penting dan sangat melekat di hati. Marung pada dasarnya kata kerja dari warung, ialah, "Tempat menjual makanan, minuman, kelontong, dan sebagainya; kedai; lepau" (Badan Pengembangan dan Pembinaan Bahasa, 2016) Penggunaan kata warung pada masyarakat Desa Paseban adalah tempat menjual makanan dan minuman, misalnya pisang goreng, nasi pecel, teh, kopi, rujak, es campur, atau makanan dan minuman tradisional yang lain. Jika yang dimaksud warung kelontong, bagi masyarakat Desa Paseban berbeda istilah dengan warung, yakni lebih dikenal dengan istilah toko/pracangan. Yang dimaksud pada budaya marung di sini adalah kebiasaan berbincang-bincang di warung bukan di toko.

Kegiatan marung bagi masyarakat Desa Paseban dianggap hal yang wajib dilakukan dalam kehidupan sehari-hari. Selain menikmati hidangan yang disajikan, bagi masyarakat Desa Paseban marung merupakan sarana untuk melepas lelah setelah bekerja di ladang atau pekerjaan lainnya, menepis rasa kesepian karena bertemu dengan tetangga, serta berbagi informasi yang dianggap penting. Topik yang sering diperbincangkan adalah masalah pertanian/perkebunan, harga kebutuhan makanan sehari-hari, pembangunan masjid/musala/program yang ada di desa, kabar terbaru dari tetangga (misalnya: pernikahan, sunatan, atau yang lain), jual beli barang bekas, kerja bakti, biaya sekolah anak, dan lainnya yang dianggap penting untuk dibahas warga. Adanya komunikasi yang membahas semua bidang di masyarakat desa telah mampu mengurangi kesenjangan pengetahuan tiap individu (Mittal, Padmaja, \& Ajay, 2018).

Berbagi (sharing) informasi yang dapat memberikan manfaat bagi orang lain melalui budaya lisan oleh masyarakat Desa Paseban, tanpa disadari telah menjadi potensi terjadinya kegiatan literasi informasi. Literasi informasi adalah kemampuan untuk berpikir kritis dan membuat penilaian yang seimbang tentang informasi yang telah ditemukan dan digunakan (CILIP, 2018).

Erza, Yusup, and Erwina (2017) telah melakukan penelitian terkait komunikasi budaya pada masyarakat Pandai Sikek (Provinsi Sumatera Barat) dalam transformasi pengetahuan lokal. Pada penelitian tersebut dijelaskan bahwa komunikasi budaya adalah upaya mempertukarkan berbagai informasi mengenai pengetahuan masyarakat Pandai 
Sikek. Komunikasi yang ada dalam bentuk nilai dan norma masyarakat. Keterkaitan antara budaya dengan komunikasi tidak dapat terpisahkan. Sekelompok masyarakat menggunakan budaya dalam berkomunikasi, sedangkan komunikasi digunakan untuk keberlangsungan suatu kebudayaan. Hal yang sama juga terjadi pada masyarakat Desa Paseban yang kemudian membentuk suatu kegiatan literasi informasi. Berdasarkan latar belakang ini, peneliti tertarik untuk menganalisis sejauh mana kegiatan literasi informasi masyarakat Desa Paseban melalui budaya marung yang telah dibangun masyarakat Desa Paseban dari zaman leluhur. Adapun tujuan dari penelitian ini adalah untuk mendeskripsikan dan menganalisis faktor apa saja yang melatarbelakangi terbentuknya budaya "marung" serta literasi informasi pada masyarakat Desa Paseban.

Walaupun terdapat persamaan penelitian terkait komunikasi budaya dalam sharing informasi atau pengetahuan, akan tetapi juga terdapat perbedaan yang mendasar antara penelitian terdahulu dengan penelitian yang dilakukan oleh penulis. Penelitian yang dilakukan oleh Erza, Yusup, and Erwina (2017) lebih menekankan pada komunikasi budaya dalam melakukan transformasi pengetahuan lokal tanpa melihat literasi informasinya. Sementara penelitian ini lebih memfokuskan pada literasi informasi melalui budaya marung. 'Marung' merupakan kebiasaan masyarakat Desa Paseban yang tidak pernah ditinggalkan sehingga menjadi budaya yang melekat pada masyarakat lokal di Desa Paseban. Sementara itu, berbagi (sharing) informasi atau pengetahuan antar masyarakat pada semua informasi atau pengetahuan yang bersifat umum, misalnya terkait pertanian, acara atau kegiatan warga, kebutuhan sekolah atau hal lain yang dianggap penting bagi masyarakat, terdiri dari "Idea dan creative process" (Zhang, Sun, Jiang, \& Zhang, 2019). Jiang and Ke (2018) malah mengatakan bahwa berbagi (sharing) informasi dapat mengurangi permasalahan yang terjadi di masyarakat. Di mana berbagi (sharing) informasi dapat dilakukan secara non formal (Nifadkar, Wu, \& Gu, 2018; Pels, 2009; Tayebi, Manesh, Khalili, \& SadiNezhad, 2019). Tetapi tidak menutup kemungkinan masyarakat juga berbagi informasi atau pengetahuan lokal, contohnya petik laut atau bahkan terkait pengetahuan lokal lain. Dengan demikian, hal ini yang menjadikan penelitian menarik untuk dikaji.

Adanya potensi kegiatan literasi informasi di warung juga dikuatkan oleh penelitian yang dilakukan Khairani (2014) terkait pendorong interaksi sosial masyarakat Aceh dalam warung kopi. Pada penelitian tersebut menunjukkan bahwa jika dilihat dari akar historis kulturalnya, warung kopi muncul sebagai pengganti hiburan, tempat berkumpul, serta tempat berbagi informasi bagi orang Aceh. Selain itu, lebih lanjut Lazuardi (2016) dalam penelitiannya mengungkapkan bahwa melalui nongkrong mahasiswa melakukan kegiatan literasi informasi, yakni mencari informasi sesuai dengan kebutuhan. Berdasarkan kegiatan diskusi dalam nongkrong, mahasiswa cenderung melakukan diskusi dalam sebuah grup. Mahasiswa mencari informasi sesuai kebutuhan, kemudian mahasiswa melakukan analisis sehingga dapat menghasilkan informasi yang akurat. Kebaruan penelitian ini jika disandingkan dengan penelitian Khairani (2014) yang lebih memfokuskan pada dorongan interaksi sosial, dan lebih menonjolkan 
kegiatan literasi informasi. Pada penelitian Lazuardi (2016) memfokuskan pada kegiatan literasi mahasiswa, yang artinya di sini adalah masyarakat yang berpendidikan dengan tujuan yang sama terkait memperoleh gelar akademik. Adapun model literasi yang digunakan adalah ACRL 2000. Berbeda dengan penelitian ini yang lebih menekankan pada kegiatan literasi informasi pada masyarakat pedesaan yang mempunyai latar belakang mata pencaharian yang berbeda-beda serta mayoritas berpendidikan rendah. Adapun model literasi yang digunakan pada penelitian ini adalah standar yang diberlakukan IFLA karena standar IFLA yang paling sesuai dengan kondisi di lapangan. Maka, judul dari penelitian ini adalah Literasi Informasi Masyarakat Desa Paseban, Kecamatan Kencong, Kabupaten Jember melalui Budaya Marung.

\section{METODE PENELITIAN}

Penelitian ini menggunakan metode penelitian kualitatif. Sugiyono (2011) dalam Ade and Affandi (2016) menyatakan bahwa penelitian kualitatif yang menggambarkan fenomena secara menyeluruh sesuai temuan lapangan termasuk ke dalam pendekatan studi deskriptif analitik. Informan yang menjadi subjek pada penelitian ini adalah masyarakat Desa Paseban yang mempunyai kebiasaan 'marung' serta masyarakat yang dianggap mempunyai pengetahuan terkait sejarah Desa Paseban. Adapun yang menjadi objek pada penelitian ini adalah terkait literasi informasi melalui budaya 'marung' serta faktor yang melatarbelakangi terjadinya literasi informasi melalui budaya 'marung'. Masyarakat Desa Paseban merupakan populasi yang telah ditentukan. Sampel pada penelitian ini menggunakan snowball dan purposive sampling, sedangkan teknik pengumpulan data yang digunakan adalah wawancara, observasi, dan dokumentasi. Tulisan ini menggunakan teknik analisis data model interaktif (Miles, Huberman, \& Saldana, 2014). Adapun langkahnya terdiri atas: (1) kondensasi data, (2) penyajian data, serta (3) penarikan kesimpulan dan verifikasi. Uji kredibilitas data yang digunakan, yakni: triangulasi sumber, triangulasi teknik, dan triangulasi waktu. Penelitian ini berlokasi di Desa Paseban, Kecamatan Kencong, Kabupaten Jember, Jawa Timur. Waktu pelaksanaan penelitian ini adalah pada tahun 2017.

\section{HASIL DAN PEMBAHASAN}

Budaya adalah segala tindakan dan tingkah laku manusia dalam kehidupan sosial yang dapat muncul dari kebiasaan sehari-hari yang memicu manusia untuk melakukan kegiatan sesuai dengan naluri, refleks dan beberapa tindakan fisiologi. Selain sebagai pola tingkah laku kehidupan sosial pada masyarakat, budaya juga memiliki andil penting dalam proses penyampaian informasi secara fisiologi seperti berkumpul dan berbincang. Selain mendefinisikan kebudayaan secara umum, secara khusus Koentjaraningrat (2009) menyebutkan bahwa terdapat 7 unsur kebudayaan yang mana sifatnya adalah universal yang di antaranya: (1) bahasa; (2) pengetahuan; (3) organisasi sosial; (4) teknologi; (5) mata pencaharian hidup; (6) religi; dan (7) kesenian. Hal ini menunjukkan bahwa manusia dalam kehidupan sehari-hari sangatlah memiliki keterkaitan erat dengan kebudayaan. Manusia dengan menggunakan kebudayaan dapat membentuk suatu pola untuk membuat, memproses, hingga menghasilkan sesuatu yang dapat membantunya dalam kegiatan sehari-hari. Manusia dalam budaya juga dapat menjalin hubungan dengan manusia lain, sehingga 
pada hal ini kebudayaan yang dimiliki seorang manusia juga berimbas kepada manusia lain. Sebagai contoh ketika manusia dikatakan hidup berkelompok atau dengan individu-individu lain, seseorang secara langsung maupun tidak langsung akan menjalin suatu komunikasi atau bertukar informasi, sehingga akan menambah pula kemampuan seseorang dalam mengembangkan pemikiran dan wawasan.

Budaya mendorong seseorang dapat berintegrasi atau memadukan berbagai unsur yang ada. Unsur yang dipadukan tersebut menjadi suatu kebudayaan yang mana bukan lagi berbentuk sekumpulan kebiasaan yang terkumpul secara acak, melainkan menjadi suatu kebudayaan yang memiliki manfaat bagi kehidupan seseorang, sehingga baik dalam kehidupannya sebagai seorang individu maupun kehidupannya sebagai seorang anggota kelompok atau masyarakat.

Serrat (2017) dalam Esariti, Yuliastuti, and Ratih (2017), mengartikan budaya adalah totalitas dari gagasan, kepercayaan, nilai-nilai, dan pengetahuan khas masyarakat. Ini menunjukkan cara manusia dalam menafsirkan lingkungannya. Teori budaya memperkuat harapan bahwa pasar kerja, bukan karena terdiri dari individu-individu otonom yang bebas dari sanksi sosial tetapi karena didukung manusia sebagai makhluk sosial, gagasan, kepercayaan, nilai-nilai, dan pengetahuan manusia yang khas. Hal ini dapat berkontribusi untuk memahami dan mempromosikan pembangunan hubungan kelompok yang lebih mendominasi. Alasan yang melatarbelakangi teori budaya tersebut adalah terdapat kebutuhan yang umum bagi semua orang setiap saat dan di semua tempat, antara lain: kebutuhan untuk mencari nafkah, kebutuhan untuk organisasi sosial, kebutuhan untuk pengetahuan dan pembelajaran, kebutuhan untuk ekspresi normatif dan metafisik, dan kebutuhan untuk mewujudkan hidup yang bahagia. Poin kebutuhan kehidupan seharihari ini dapat diperoleh melalui ranah lingkungan, ekonomi, masyarakat, politik, dan teknologi yang saling melengkapi untuk membentuk sistem keberlanjutan bersama atau (dalam oposisi) kerentanan bersama.

Berdasarkan teori budaya dan kebutuhan manusia menunjukkan bahwa kebutuhan seseorang mendasari terbentuknya budaya yang ada di masyarakat. Langkah nyata untuk memenuhi kebutuhan tersebut menghasilkan suatu tradisi atau kebiasaan pada masyarakat tersebut.

Selain itu Koentjaraningrat (2009) menyebutkan bahwa, "Kebudayaan sendiri memiliki empat sistem yang mana sistem tersebut digunakan dalam menganalisis kebudayaan secara keseluruhan, keempat sistem tersebut yaitu: sistem budaya, sistem sosial, sistem kepribadian, sistem organisme". Dari sistem tersebut memiliki keterkaitan erat satu dengan lainnya, tetapi merupakan entitas khusus pada masingmasing sistem dan memiliki sifat tersendiri pada setiap sistem.

Pada sistem budaya, komponen abstrak dari kebudayaan yang terdiri dari pikiran, gagasan, konsep, tema berpikir, dan keyakinan. Dengan demikian, sistem budaya adalah bagian dari kebudayaan yang mempunyai nilai budaya dan norma, yang mana secara khusus dapat diperinci ke dalam berbagai macam norma menurut aturan-aturan yang ada dalam masyarakat bersangkutan. Budaya sendiri memiliki fungsi untuk menata dan memantapkan tindakan serta tingkah laku manusia. 
Sistem sosial terdiri dari aktivitas manusia dan tingkah laku yang berinteraksi dengan individu lainnya dalam kehidupan bermasyarakat. Rangkaian tindakan yang berkaitan satu dengan lainnya, sistem sosial juga lebih bersifat konkret dan nyata daripada sistem budaya, dalam artian bahwa tindakan manusia dapat dilihat dan diobservasi. Interaksi manusia di suatu pihak ditata dan diatur oleh sistem budaya, akan tetapi di pihak lain budaya diubah menjadi pranata melalui nilai dan norma tersebut, sehingga aktivitas manusia dalam berkehidupan dapat dilihat atau diobservasi dan dapat diatur sesuai dengan aturan atau norma yang ada.

Sistem kepribadian adalah sistem yang berisikan tentang jiwa manusia dan watak individu yang berinteraksi sebagai anggota masyarakat. Kepribadian seorang individu dalam suatu masyarakat atau kelompok, berbeda satu dengan lainnya. Kepribadian seorang individu distimulasi dan dipengaruhi nilai dan norma dalam sistem budaya dan sistem sosial. Hal ini membuat pola yang telah diinternalisasikan melalui proses sosialisasi dan proses pembudayaan selama hidup. Dengan demikian, sistem kepribadian individu berfungsi sebagai sumber motivasi dari tindakan sosialnya.

Terakhir adalah sistem organik, yang mana sistem ini melengkapi keseluruhan dari kerangka yang dibuat dengan mengikutsertakan ke dalamnya proses biologis dan biokimia pada organisme manusia sebagai suatu jenis makhluk alamiah yang apabila dipikirkan lebih mendalam juga ikut menentukan kepribadian individu, pola tindakan manusia, dan bahkan juga gagasan yang telah dicetuskan.

Berdasarkan keempat sistem yang telah dijelaskan Koentjaraningrat (2009), seorang individu dalam berbudaya akan memiliki kemampuan untuk: 1) menata dan memantapkan tindakan serta tingkah laku manusia; 2) melakukan observasi dan melihat tingkah laku manusia dan mengatur sesuai dengan norma dan aturan yang berlaku; 3) menggunakan kemampuan pribadi sebagai motivasi dalam melakukan tindakan sosial; dan dapat menentukan kepribadian dari individu lain melalui pola dan gagasan yang dicetuskan.

Budaya marung berasal dari kata budaya dan marung. Marung merupakan kata kerja dari kata warung. Warung adalah "Tempat menjual makanan, minuman, kelontong, dan sebagainya; kedai; lepau" (Badan Pengembangan dan Pembinaan Bahasa, 2016). Budaya marung dapat diartikan sebagai budaya atau kebiasaan yang melekat pada kehidupan masyarakat dengan mengunjungi warung.

Anshoriy Ch. (2008) dalam Widayanti (2016) mengungkapkan bahwa karakteristik masyarakat pedusunan di Jawa mempunyai keunikan yang khusus, misalnya: ikatan emosional yang tergolong tinggi, sederhana, kesenian rakyat dan loyalitas atau menjunjung tinggi kesetiaan pada pimpinan kulturan yakni terkait konsep yang berkembang di pedusunan sebagai seluk beluk masyarakat. Kekayaan yang dimiliki bangsa Indonesia adalah budaya dan keanekaragaman hayati sehingga hal ini menunjukkan adanya hubungan yang sangat erat dan berpengaruh terhadap karakteristik masyarakat.

Lebih lanjut Murdiyanto (2008) dalam Ismaini (2013) menyatakan bahwa kehidupan desa sangat kental dalam hal mengatur masyarakat sekitar. Pertama, tetangga mempunyai potensi untuk mengatur sekitar sehingga dapat mengubah kehidupan keluarga. Di samping itu, 
kehidupan bertetangga juga memberikan dasar saling membantu, saling melakukan kunjungan sosial, serta kerap kali hubungan diperkuat dengan adanya aktivitas bermain bersama anak-anak.

Kedua, individu mengenal diri mereka sendiri yang juga termanifestasi dalam pandangan masyarakat. Ketiga, dalam kehidupan bermasyarakat, kelompok informal menjadi ada untuk berbagai tujuan, misalnya bergosip, malas-malasan, minuman, main kartu dan aktivitas informal lainnya.

Berdasarkan hal ini budaya marung termasuk kegiatan dalam kelompok informal. Dilihat dari tujuannya, budaya marung berpotensi menghasilkan hal yang negatif, contohnya bergosip yang justru menimbulkan keresahan di masyarakat, bermalas-malasan atau menghindari tanggung jawab dengan bersantai-santai di warung, minum dan makan secara berhutang terus-menerus bahkan ada yang tidak membayar sehingga merugikan pemilik warung, atau aktivitas informal lainnya yang cenderung negatif. Tidak dapat dipungkiri hal tersebut juga terjadi.

Tidak hanya itu, budaya marung mempunyai tujuan positif, misalnya menjalin silaturahmi, ingin mendapatkan informasi dari hasil perbincangan, untuk mencari hiburan dan melepas lelah setelah bekerja, mengoordinasikan kegiatan warga secara santai. Hal ini tanpa disadari dapat terjadi adanya kegiatan literasi informasi.

Menurut Luthfia (2013), desa di Indonesia diasosiasikan identik dengan masyarakat yang memiliki sifat jujur, hidup sederhana, mayoritas berpendidikan rendah, menjunjung tinggi ikatan sosial, bersahaja, serta memegang teguh adat dan tradisi. Budaya marung merupakan kebiasaan yang tidak bisa lepas dari kehidupan masyarakat Desa Paseban.
Ikatan sosial yang sangat erat juga menjadi penyebab budaya marung dapat tumbuh subur sampai saat ini. Walaupun mayoritas masyarakat berpendidikan rendah, akan tetapi hal itu tidak menjadi penghalang bagi masyarakat untuk selalu bertukar informasi, menganalisisnya serta mengaplikasikannya dengan tujuan memberikan manfaat bagi hidupnya baik dari sisi religius maupun untuk mendukung pekerjaannya.

Informasi telah menjadi komoditas penting bagi masyarakat desa karena dapat membantu mengatasi persoalan di kehidupan sehari-hari. Taeko (2013) mengatakan bahwa literasi di masyarakat desa memiliki arti dan memainkan peran yang berbeda di masyarakat. Menurut Lau (2006), sesuai standar IFLA, literasi dikelompokkan menjadi beberapa komponen. Pertama, akses. Pemustaka mengakses informasi secara efektif dan efisien melalui identifikasi dan lokasi informasi. Mengidentifikasi kebutuhan informasi terdiri atas: (a) menemukan atau mengenali kebutuhan informasi, (b) memutuskan suatu tindakan untuk menemukan informasi, (c) menyatakan dan menentukan kebutuhan informasi, dan (d) memulai proses pencarian. Lalu dalam lokasi informasi, terdiri atas: (a) mengidentifikasi dan mengevaluasi sumber informasi yang potensial, mengembangkan strategi pencarian, (c) mengakses sumber informasi terpilih, dan (d) memilih dan menemukan lokasi informasi.

Kedua, evaluasi. Pemustaka mengevaluasi informasi secara kritis, kompeten melalui penilaian informasi dan organisasi informasi. Penilaian informasi, terdiri atas: (a) menganalisis, memeriksa, dan menyaring informasi, menggeneralisasi dan menginterpretasikan informasi, (c) memilih dan menggabungkan 
informasi, dan (d) mengevaluasi keakuratan dan hubungan dari informasi yang ditemukan. Lalu dalam organisasi informasi, terdiri atas: (a) mengatur dan mengkategorikan informasi, mengelompokkan dan mengatur informasi yang didapat, dan (c) menentukan informasi yang sering digunakan dan baik.

Ketiga, mengenai penggunaan. Pemustaka dapat menggunakan informasi secara akurat dan kreatif melalui penggunaan informasi, komunikasi dan etika penggunaan informasi. Penggunaan informasi, terdiri atas: (a) menentukan cara baru untuk mengkomunikasikan, menyajikan, dan menggunakan informasi, (b) mengaplikasikan informasi yang ditemukan, (c) mempelajari atau mendalami informasi sebagai pengetahuan pribadi, (d) mempresentasikan hasil informasi. Komunikasi dan etika penggunaan informasi, terdiri atas: (a) memahami etika penggunaan informasi, (b) menghormati peraturan penggunaan informasi, (c) mengkomunikasikan hasil pembelajaran dengan pengetahuan intelektual yang dimiliki, (d) menggunakan pengetahuan yang relevan dan sesuai dengan standar yang ada.

Keterampilan informasi sangat penting untuk keberhasilan pembelajaran seumur hidup, pekerjaan, dan komunikasi antarpribadi setiap hari dari setiap warga negara, seperti ketika seseorang membutuhkan informasi tentang layanan kesehatan untuk seseorang dalam perawatan, atau seorang siswa memerlukan informasi spesifik untuk menyelesaikan penilaian. Informasi kesehatan yang benar memang penting diketahui oleh masyarakat (Kim, 2010). Crook, Stephens, Pastorek, Mackert, and Donovan (2015) menambahkan bahwa informasi kesehatan di masyarakat rendah dan terkait perubahan dunia kesehatan dan pengalaman individu

Bruce (2016) pun mengatakan demikian, bahwa masyarakat yang memiliki keterampilan informasi dapat membangun dan mengembangkan potensi daerahnya. Lau (2006) mengatakan bahwa pedoman standar literasi IFLA telah disusun oleh Bagian Literasi Informasi (InfoLit) dari IFLA dengan tujuan memberikan kerangka pragmatis bagi para profesional yang membutuhkan atau tertarik untuk memulai program literasi informasi.

Warisan budaya merupakan produk atau hasil budaya (Baker, 2013). Untuk menanamkan keterampilan berpikir kritis, perlu mempertimbangkan kepekaan budaya, dan latar belakang budaya yang berbeda di mana keterampilan berpikir kritis belum ada, dalam konteks pembelajaran warisan budaya. keterampilan berpikir kritis utama diuraikan, dan contoh ilustratif ketika kepekaan budaya begitu meningkat sehingga semua debat dan dialog kritis ditutup untuk mendukung kebutuhan akan kepekaan dalam pelatihan (Baker, 2013). Senada dengan Bird, Crumpton, Ozan, and Williams (2012) yang menyebutkan, "Critical thinking skills and information-seeking behaviors factor in deter- mining how to evaluate and use the information appropriately". Masyarakat yang memiliki keterampilan berpikir kritis dan keahlian mencari informasi menentukan proses evaluasi dan menggunakan informasi tersebut.

Definisi literasi informasi pada abad 21 telah dijelaskan Campbell (2008) bahwa IFLA memiliki peran dalam memperluas definisi praktis untuk memasukkan semua bentuk literasi informasi untuk semua orang atau kalangan masyarakat. Hal ini menunjukkan bahwa kebiasaan 'marung' merupakan produk budaya dan bisa 
dianggap sebagai warisan budaya bukan benda yang berupa tradisi. Jika dilihat dari peran IFLA, literasi informasi bisa terjadi di mana saja dan dapat saja terjadi pada semua orang dengan latar belakang yang berbeda, termasuk dalam kegiatan 'marung' pada masyarakat Desa Paseban.

Budaya marung berasal dari kata budaya dan marung. Marung merupakan kata kerja dari kata warung, adalah "Tempat menjual makanan, minuman, kelontong, dan sebagainya; kedai; lepau" (Badan Pengembangan dan Pembinaan Bahasa, 2016). Budaya marung dapat diartikan sebagai budaya atau kebiasaan yang melekat pada kehidupan masyarakat dengan mengunjungi warung. Terbentuknya budaya "marung" pada dasarnya berasal dari asal muasal sejarah dari masyarakat desa. Ketika masyarakat desa masih dalam masa penjajahan Belanda, masyarakat desa berusaha untuk mempertahankan diri. Adapun cara untuk mempertahankan diri adalah dengan mengatur strategi pertahanan yang dianggap strategi paling baik menurut masyarakat desa. Strategi pertahanan tersebut adalah dengan cara memecah satu desa (Desa Cakru) menjadi dua desa, yakni (Desa Cakru dan Desa Paseban). Desa Cakru yang asal penamaannya dari kata cangkruk/cangkrukan (berkumpul untuk berjaga-jaga), kemudian menjadi strategi dalam melawan penjajahan Belanda. Desa Cakru yang berada di sebalah utara bertugas menjadi penjaga, bertugas berjagajaga dari penjajahan Belanda, sedangkan Desa Paseban letaknya di sebelah selatan dekat dengan Pantai Selatan/Samudera Hindia maka dijadikan sebagai tempat peristirahatan terakhir (perseboan). Jadi kata Paseban berasal dari kata perseboan. Tempat peristirahatan terakhir ini (perseboan) berfungsi sebagai: 1) tempat peristirahatan bagi masyarakat desa yang telah berjaga/cangkruk untuk melepas lelah, 2) tempat peristirahatan bagi masyarakat yang terluka karena serangan penjajah Belanda, 3) tempat peristirahatan bagi masyarakat yang terserang penyakit/dalam keadaan sakit, dan 4) tempat peristirahatan terakhir bagi masyarakat yang tutup usia/meninggal. Masyarakat menganggap bahwa Desa Paseban dijadikan sebagai peristirahatan terakhir (perseboan), karena dianggap tempat paling aman dan tidak mungkin dapat dijamah oleh penjajah Belanda dan juga anginnya yang sepoisepoi dan suasana yang tenang dianggap dapat memberikan ketenteraman jiwa bagi masyarakat desa. Hal ini dikarenakan Desa Paseban terletak tepat di bibir pantai kawasan Samudera Hindia.

Pada saat cangkruk (berjaga-jaga) masyarakat desa dituntut mempunyai stamina yang bagus. Masyarakat desa dituntut untuk dapat bertahan tidak tidur siang dan malam bahkan sampai beberapa hari. Maka masyarakat desa menggunakan strategi meminum kopi, sehingga di saat cangkruk tidak ketinggalan dengan kopi. Kopi merupakan teman sejati bagi masyarakat yang bertugas menjadi penjaga pada saat itu. Setelah masa penjajahan Belanda berakhir, kebiasaan cangkrukan ini menjadi melekat pada masyarakat desa bahkan diwariskan secara turun-temurun. Perlu tempat yang dianggap paling strategis untuk berkumpul/cangkrukan. Di mana tempat ini bisa menampung semua masyarakat dari berbagai latar belakang untuk sekadar berbincang, bersenda gurau, menjalin silaturahmi, melepas lelah dari kegiatan sehari-hari, mendapat informasi yang dibutuhkan, dan tentunya tetap ditemani minum kopi sebagai teman berbincang sehingga muncul warungwarung yang bertebaran di setiap sisi desa. 
Hal ini terbukti dengan data jumlah warung yang ada di Desa Paseban, yakni berjumlah 45 warung. Bagi pengunjung warung, kagiatan marung merupakan suatu kegiatan cangkrukan yang dapat memenuhi kebutuhan psikis dan fisik. Bagi pemilik warung, hal ini ditangkap sebagai peluang usaha untuk meningkatkan pendapatan ekonomi dan juga mendapatkan teman berbincang di warung. Maka hal ini menjadi hal yang dapat memberikan keuntungan bagi kedua belah pihak, baik bagi pengunjung warung maupun pemilik warung, yakni terdapat hubungan simbiosis mutualisme. Hal inilah yang menyebabkan warung-warung menjadi menjamur di Desa Paseban dan berlangsung hingga sekarang. Berdasarkan hal tersebut, kegiatan marung menjadi kebiasaan yang terus dilakukan dan sangat melekat di hati masyarakat desa yang berkembang menjadi budaya.

Komponen abstrak masyarakat Desa Paseban yang terkait dengan budaya marung di antaranya berawal dari strategi cangkruk/cangkrukan yang menjadi strategi pertahanan dalam masa penjajahan Belanda. Lalu budaya cangkruk/cangkrukan terus berlanjut hingga sekarang melalui budaya marung. Kegiatan marung dianggap kegiatan yang dapat memenuhi kebutuhan psikis dan fisik.

Sistem sosial budaya marung masyararakat Desa Paseban sendiri adalah berawal dari strategi cangkruk/cangkrukan yang menjadi strategi pertahanan dalam masa penjajahan Belanda. Hal ini dapat dilihat dari interaksi masyarakat yang bertugas cangkruki berjaga dengan dituntut tidak boleh lengah dari penjajah Belanda. Masyarakat desa tidak boleh menjadi penghianat bagi saudaranya. Masyarakat desa yang bertugas menjadi penjaga bertugas memata-matai/mengintai tindakan penjajah Belanda. Jika terdapat masyarakat yang justru menjadi penghianat, maka akan mendapatkan hukuman oleh masyarakat desa.

Budaya cangkruk/cangkrukan terus berlanjut hingga sekarang melalui budaya marung. Kegiatan marung dianggap kegiatan yang dapat memenuhi kebutuhan psikis dan fisik. Maksud dari kebutuhan psikis dan fisik di sini adalah kebutuhan psikis masyarakat desa baik pengunjung warung maupun pemilik warung. Adapun kebutuhan psikis pengunjung warung dan pemilik warung, adalah: berbincang, bersenda gurau, menjalin silaturahmi, melepas lelah dari kegiatan sehari-hari, dan mendapat informasi yang dibutuhkan. Kebutuhan fisik pengunjung warung adalah dapat membeli makanan dan minuman yang diinginkan untuk melepas rasa lapar dan dahaga sedangkan kebutuhan fisik pemilik warung adalah warung merupakan peluang usaha untuk mendapat penghasilan dalam memenuhi kebutuhan sehari-hari. Schneider et al., (2017) malah mengatakan bahwa makanan dan minuman menjadi salah satu bentuk area publik yang memperlihatkan perubahan.

Bagi masyarakat desa yang membuat onar di warung baik dengan tingkah laku maupun pembicaraan yang dianggap mengganggu atau menyakiti sesama masyarakat desa yang sedang marung, maka akan diusir dari warung dan diberi tindakan yang menurut masyarakat desa pantas sebagai hukuman. Terkait kepemimpinan komunitas lokal dan perkembangan global dalam sejarah menunjukkan bahwa dalam kehidupan bermasyarakat layaknya permainan yang diulang sebagai model mendasar bagaimana orang-orang yang hidup bersama dalam komunitas kecil dapat mendisiplinkan diri untuk mempertahankannya secara maya setiap 
pola perilaku yang adaptif untuk kelangsungan hidup masyarakat. Hal ini dibuktikan adanya strategi di mana siapa pun yang menyimpang dari perilaku yang ditentukan maka akan diperlakukan secara tidak baik, sehingga menyebaban perubahan status yang merugikan di komunitas dan karenanya akan diperlakukan lebih buruk oleh orang lain di komunitas sesudahnya. Myerson (2017) pun mengatakan bahwa beberapa aspek dari strategi tersebut tertanam dalam otak manusia, seperti kecenderungan untuk menilai kepatutan dari perilaku orang lain di suatu komunitas dan ketakutan timbal balik kehilangan status di mata masyarakat tersebut.

Sistem kepribadian pada budaya marung masyarakat Desa Paseban adalah berawal dari strategi cangkruk/cangkrukan yang menjadi strategi pertahanan dalam masa penjajahan Belanda, dari sini terbentuk sistem kepribadian nasionalisme. Lalu budaya cangkruk/cangkrukan terus berlanjut hingga sekarang melalui budaya marung. Kegiatan marung dianggap kegiatan yang dapat memenuhi kebutuhan psikis dan fisik. Di sini terbentuk sistem kepribadian guyub, rukun, akrab, dan menjaga silaturahmi.

Sistem organik pada budaya marung masyarakat Desa Paseban adalah berawal dari strategi cangkruk/cangkrukan yang menjadi strategi pertahanan dalam masa penjajahan Belanda. Dari sini terdapat sistem organik akan kebutuhan rasa aman oleh masyarakat desa dalam menjalani kehidupan, baik kebutuhan rasa aman dalam hal kebutuhan psikis maupun kebutuhan biologis. Kebutuhan biologis yang dikedepankan di sini adalah tempat perlindungan. Masyarakat desa berpikir bagaimana cara melindungi dirinya dari ancaman pihak penjajah Belanda.
Masyarakat desa menciptakan strategi penahanan dengan model cangkurakan dan perseboan.

Budaya cangkruk/cangkrukan terus berlanjut hingga sekarang melalui budaya marung. Kegiatan marung dianggap kegiatan yang dapat memenuhi kebutuhan psikis dan fisik. Dari sini terdapat sistem organik akan kebutuhan untuk melepaskan rasa lapar dan dahaga, melepaskan lelah/penat setelah bekerja/melakukan kegiatan seharihari (istirahat), serta membutuhkan tempat untuk beraktivitas di luar pekerjaan/kegiatan sehari-hari dengan cara berinteraksi dengan orang lain di tempat yang dianggap santai dan nyaman.

Budaya "marung" telah menjadi bagian dari kehidupan masyarakat Desa Paseban. Mereka sudah terbiasa "marung" baik ketika akan berangkat kerja, saat istirahat siang, pulang kerja bahkan ketika malam hari. Perbedaan latar belakang baik pekerjaan atau usia saat masyarakat "marung" menyebabkan obrolan yang mereka lakukan menjadi menarik.

Hasil analisis Bruce et al. (2017) terkait desain pengalaman informasi yang dikemukakan oleh Elham Sayyad Abdi, yang menunjukkan bahwa rancangan pengalaman informasi adalah tentang memperluas pengalaman orang-orang akan informasi dalam konteks khusus hingga batas maksimalnya. Hal ini menyangkut tentang bagaimana mengembangkan dan mengimplementasikan intervensi yang memungkinkan individu dan kelompok mengalami informasi dan lingkungan informasi di sekitarnya dalam berbagai cara yang semakin kompleks yang menawarkan pengalaman untuk terlibat secara lebih kaya, lebih luas, dan lebih efektif dalam informasi. Individu di masyarakat melalui literasi informasi akan mudah memahami tiap bidang kehidupan di lingkungannya 
secara etik dan legal (Deyrup, 2009). Selain itu, Weiner, Jackman, and Prause( 2013) menambahkan bahwa individu pun dapat memilih sumber informasi yang sesuai dengan kebutuhan informasinya.

Desain pengalaman informasi dimulai dengan investigasi terhadap pengalaman informasi seseorang. Ini melibatkan seluruh pengalaman fenomena dan komponen informasi dari pengalaman tersebut. Hasil dari investigasi semacam ini akan menjadi uraian tentang bagaimana, dengan cara yang berbeda, orang terlibat atau melepaskan informasi dalam konteks tertentu. Maka, informasi di bidang ekonomi merupakan jenis informasi yang rata-rata dibutuhkan masyarakat (Sokoloff, 2012).

Literasi informasi terletak pada inti dari pembelajaran seumur hidup. Hal ini berarti memberdayakan orang di semua lapisan masyarakat untuk mencari, mengevaluasi, menggunakan, dan membuat informasi secara efektif untuk mencapai tujuan pribadi, sosial, pekerjaan dan pendidikan mereka (Arua et al., 2018). Konsep literasi tersebut adalah bagaimana keterampilan dibutuhkan ketika orang akan mengkritisi isi dari sebuah informasi juga cara menggunakan informasi yang efektif serta pemahaman tentang infrastrukur teknologi informasi yang berbasis konteks sosial. Keterampilan seperti itu dinamakan dengan melek informasi. Keberagaman latar belakang pekerjaan yang terjadi ketika mereka "marung" bisa membuat mereka menjadi melek informasi. Contohnya, para Petani Desa Paseban bisa mendapatkan informasi mengenai harga komoditas pertanian di pasaran dari mereka yang berprofesi sebagai pedagang. Setelah mereka mendapatkan informasi harga mereka bisa memungkinkan melakukan negosiasi yang maksimal ketika ada tengkulak yang ingin membeli hasil panen mereka. Selain itu, pun mengatakan demikian, bahwa bagi para petani, informasi menjadi solusi penting di kehidupan masyarakat desa (Fatimah, Yunita, Gunardi, 2018; Toepfer, Kuhlmann, Kansiime, Onyango, Davis, Cameron, \& Day, 2018).

Berdasarkan hasil analisis di atas menunjukkan bahwa terdapat keterkaitan yang sangat erat antara budaya marung dengan literasi informasi. Kegiatan literasi informasi juga berhubungan dengan teori ruang publik yang diungkapan oleh Habermas. Hardiman (2010) dalam Kuncoro (2013) Ruang publik terbentuk di masyarakat yang duduk berkumpul bersama dan berdiskusi mengenai tematema yang relevan. Adapun tema-tema yang dianggap relevan bagi masyarakat Desa Paseban adalah tema-tema yang berhubungan dengan kebutuhan informasi dalam menjalani kehidupan sehari-hari. Ruang publik (public sphere) terbentuk secara alamiah melalui budaya marung yang bertempat di warung. Bagi masyarakat Desa Paseban, warung merupakan titik kumpul yang strategis untuk melakukan diskusi sekaligus melepas lelah dan sebagai tempat penyegaran kembali (refreshing) yang sangat nyaman.

Ketika masyarakat sedang melakukan aktivitas, obrolan yang terjadi ketika masyarakat sedang melakukan aktivitas "marung" tidaklah jauh dari kehidupan sehari-hari mereka. Topik yang biasanya menjadi bahan obrolan mereka ketika "marung" adalah pekerjaan, pendidikan ataupun isu-isu yang terkait dengan Desa Paseban. Ketika mereka "marung" obrolan yang mereka lakukan berjalan dua arah atau kelompok sehingga dari obrolan tersebut menimbulkan sebuah informasi yang bisa mereka manfaatkan. 
Pembahasan informasi yang terjadi pada saat "marung" biasanya merupakan hal-hal yang berguna untuk menunjang mata pencaharian mereka. Obrolan ketika "marung" berawal dari kebutuhan pekerjaan. Contohnya adalah ketika ada petani yang menanam semangka bersamaan dengan musim ombak besar di laut selatan, maka para nelayan akan beralih pekerjaan menjadi petani semangka, mengingat semangka yang dihasilkan dinilai layak. Pembahasan ini sering muncul ketika masyarakat sedang "marung". Berdasarkan pembahasan-pembahasan itu tidak jarang memunculkan sebuah gagasan yang bisa mempermudah beban pekerjaan mereka. Seperti masalah nelayan yang sering kesulitan modal. Setelah masyarakat berbincang mengenai usaha nelayan saat "marung", maka muncul ide untuk membuat koperasi bagi nelayan dan petani dengan tujuan supaya kehidupan nelayan menjadi lebih baik dari kondisi saat ini.

Pembahasan informasi saat "marung" tidak melulu hal pekerjaan. Mereka juga sering membahas hal-hal yang menjadi hiburan bagi mereka. Masyarakat juga sering "marung" ketika mereka pulang dari sawah. Setelah bekerja seharian tentunya mereka ingin melepas penat dengan berbincang santai dengan pengunjung lain atau pemilik warung. Ketika mereka berbincang tentunya tidak semua informasi akan berguna bagi kehidupan mereka. Masyarakat akan memilah mana informasi yang sifatnya informatif dan mana yang sifatnya rekreatif. Mereka memilahnya tanpa perlu mengetahui secara teori mana yang informatif mana yang rekreatif. Setelah mereka menemukan informasi yang sesuai dengan kebutuhan saat "marung", maka mereka menerapkannya untuk menunjang di keseharian.
Pertama, masyarakat Desa Paseban telah melakulan proses dari komponen akses ini. Komponen akses ini sendiri secara singkat merupakan bagaimana masyarakat mengakses informasi secara efektif dan efisien. Akses mempunyai kaitan dengan cara masyarakat mengindentifikasi kebutuhan informasi dan lokasi dari informasi. Masyarakat Desa Paseban sudah bisa mengidentifikasi kebutuhan informasi mereka.

Masyarakat yang bertempat tinggal di Dusun Bulurejo dan Dusun Paseban memiliki pekerjaan sebagai nelayan, petani, atau keduanya (nelayan sekaligus petani) karena letak dusun mereka yang ada di pesisir pantai. Kondisi berbeda dialami dengan masyarakat dari Dusun Balekambang yang bermata pencaharian sebagai petani, peternak atau pedagang, mengingat wilayah dusun mereka memiliki banyak lahan pertanian. Masyarakat tidak mengalami kesulitan dalam mengenali kebutuhan informasi yang sesuai dengan latar belakang mereka.

Identifikasi kebutuhan informasi mereka sering terjadi ketika mereka sedang "marung". Warung kopi berperan sebagai lokasi informasi ketika mereka mengidentifikasi dan mengevaluasi sumber informasi yang ideal. Peran lain dari warung kopi adalah sebagai wadah penyaluran informasi atau tempat pemenuhan kebutuhan informasi. Ketika masyarakat sedang membutuhkan informasi, yang menjadi tujuan pertama dari mereka adalah warung kopi, karena ketika "marung" mereka bisa mendapatkan semua informasi yang mereka butuhkan. Bahkan ketika mereka hanya sekedar "marung" tanpa tujuan mencari informasi mereka bisa tetap mendapatkan informasi. Kegiatan "marung" bisa berperan sebagai sarana edukatif yang bisa digunakan untuk 
menunjang aktivitas bekerja mereka. Budaya "marung" pun bisa menjadi sarana rekreatif ketika mereka meluangkan waktu ke warung untuk menikmati kopi sembari mendengarkan cerita yang ramai diperbincangkan oleh para pengunjung lainnya.

Pada komponen kedua ini yakni evaluasi, masyarakat dituntut untuk mengevaluasi informasi yang mereka peroleh secara kritis dan kompeten. Mereka melakukan penilaian informasi lalu kemudian dilakukan pengelompokan informasi. Kegiatan "marung" telah memberikan ruang lebih pada penerapan indikator ini karena implementasi kegiatan "marung" sangat dekat dengan kegiatan diskusi ataupun perbincangan ringan.

Proses evaluasi bisa terjadi ketika masyarakat menilai informasi dengan cara menganalisis, memeriksa dan menyaring informasi. Setelah itu informasi lalu digeneralisasi dan dinterpretasi. Kemudian informasi itu pilih dan digabungkan sebelum informasi tersebut dievaluasi keakuratan dan hubungan dari informasi yang ditemukan. Evaluasi informasi tidak hanya dengan penilaian informasi saja, namun juga pengorganisasian informasi, di mana informasi itu diatur dan dikategorikan. Setelah mereka mengategorikan informasi, informasi dikelompokan dan diatur sesuai informasi yang didapatkan. Kemudian mereka menentukan informasi mana yang sering digunakan dan baik.

Masyarakat Desa Paseban dalam kesehariannya telah melakukan evaluasi informasi tanpa mereka sadari. Contohnya ketika sedang membahas mengenai bibit bantuan, mereka menilai bibit yang mereka terima itu tidak sesuai dengan karakter tanah di Desa Paseban yang menyebabkan banyak bibit gagal berkembang. Tentunya, mereka tidak bisa langsung mengatakan bahwa bibit bantuan tersebut tidak sesuai. Mereka mencoba beberapa kali mengevaluasi informasi terkait bibit bantuan tersebut, ternyata bibit tersebut tidak cocok untuk pertanian di desa. Proses evaluasi informasi tidak hanya dari pengalaman saja, namun juga terbantu dengan adanya kehadiran teknologi. Mereka menggunakan handphone untuk mencari kebenaran dari sebuah informasi yang diterima.

Masyarakat Desa Paseban dikatakan telah melakukan indikator yang ketiga ini, meskipun sebenarnya mereka tidak mengetahui apa itu indikator literasi informasi. Pada indikator ini kegiatan "marung" yang terjadi adalah proses masyarakat mengkomunikasikan informasi yang telah mereka dapatkan secara pribadi kepada orang lain. Konsep sebenarnya dari indikator ini, masyarakat menggunakan informasi dengan menentukan cara untuk mengkomunikasikan informasi, menyajikannya dan menggunakan informasi. Informasi yang ditemukan lalu diaplikasikan dalam kehidupan mereka. Setelah itu, informasi dipelajari sebagai pengetahuan pribadi mereka. Setelah mereka paham, maka mereka akan mempresentasikan kepada orang lain dengan cara bercerita ke orang yang merek temui.

Indikator yang ketiga, yakni komunikasi dan etika penggunaan informasi. Konsep sederhananya, masyarakat memahami etika dari penggunaan informasi, kemudian aturan dari penggunaan informasi itu harus dihormati dan tidak bisa seenaknya sendiri. Lalu hasil pembelajaran dari informasi yang mereka miliki dikomunikasikan melalui pengetahuan yang mereka miliki sebelumnya. Setelah itu, mereka 
menggunakan pengetahuan yang relevan dan sesuai standar yang ada.

Masyarakat Desa Paseban dalam kesehariannya sudah sering melakukan indikator ini. Mereka membawa informasi yang didapatkan dari pengalaman ketika sedang "marung". Di sana, mereka akan menceritakannya kepada pengunjung warung kopi lainnya. Sumber informasi tak hanya dari pengalaman mereka saja, namun juga bisa dari televisi. Mereka terkadang setelah mendapatkan sebuah berita di televisi akan membawa berita tersebut pada saat "marung" dan akan membahasnya bersama pengunjung lainnya.

\section{SIMPULAN}

Sejarah pada masa penjajahan Belanda menjadi faktor utama terbentuknya budaya marung pada masyarakat Desa Paseban. Budaya marung sangat lekat dengan budaya cangkrukan/berkumpul untuk berbincang-bincang sambil meminum kopi. Warung dianggap tempat yang paling strategis untuk berbincang, bersenda gurau, menjalin silaturahmi, melepas lelah dari kegiatan sehari-hari, serta mendapat informasi yang dibutuhkan. Budaya marung memenuhi empat sistem budaya, yakni: sistem budaya, sistem sosial, sistem kepribadian, dan sistem organisme. Budaya marung sangat erat kaitannya dengan literasi informasi dan teori ruang publik. Masyarakat Desa Paseban secara sederhana telah menerapkan Standar Literasi Informasi dari IFLA dalam mendukung pekerjaannya dari tahap akses, evaluasi, dan penggunaan. Sederhana yang dimaksud di sini adalah masyarakat desa sudah menerapkannya namun masih belum bisa menerapkan konsep literasi informasi secara mendalam/detail dari masingmasing tahapan. Pada kegiatan literasi informasi ini, masyarakat Desa Paseban berkumpul di warung dan saling berdiskusi mengenai topik-topik yang dianggap relevan dengan informasi yang dibutuhkan masyarakat dalam menjalani kehidupan sehari-hari. Rencana penelitian selanjutnya, peneliti akan melakukan inovasi penelitian terkait model pengembangan program perpustakaan desa dalam rangka menumbuhkan literasi informasi melalui warung yang ada di masyarakat.

\section{DAFTAR PUSTAKA}

Ade, V., \& Affandi, I. (2016). Implementasi nilai-nilai kearifan lokal dalam mengembangkan keterampilan kewarganegaraan: Studi deskriptif analitik pada masyarakat Talang Mamak Kec. Rakit Kulim, Kab. Indragiri Hulu Provinsi Riau. Jurnal Pendidikan Ilmu Sosial, 25(1), 77-91. https://doi.org/10.17509/jpis.v25i1.36 71

Arua, G. N., Eze, O. C., Ebisi, E. M., Ukwuaba, H. O., Ezeanuna, E. F., \& Nwebiem, C. P. (2018). Information literacy for empowering the society: The readiness of libraries, librarians and other stakeholders. In Satellite Meeting Paper: Africa, Libraries as Centers of Community Engagements for Development (pp. 1-14). Kuala lumpur: IFLA Publication. Retrieved from http:/ / library.ifla.org/2312/1/s012018-aura-en.pdf

Badan Pengembangan dan Pembinaan Bahasa. (2016). Kamus besar bahasa Indonesia (5th ed.). Jakarta: Kementerian Pendidikan dan Kebudayaan.

Baker, K. (2013). Information literacy and cultural heritage: Developing a model of lifelong learning. New Delhi: Chandos Publishing. 
Bird, N. J., Crumpton, M., Ozan, M., \& Williams, T. (2012). Workplace information literacy: A neglected priority for community college libraries. Journal of Business \& Finance Librarianship, 17(1), 18-33. https://doi.org/10.1080/08963568.2012 .630593

Bruce, C. S., Demasson, A., Hughes, H., Lupton, M., Abdi, E. S., Maybee, C., Somerville, ... Mirijjamdotter, A. (2017). Information literacy and informed learning: Conceptual innovations for il research and practice futures. Journal of Information Literacy, 11(1), 4-22. https://doi.org/10.11645/11.1.2184

Bruce, C. S. (2016). Information literacy research: Dimensions of the emerging collective consciousness. A reflection. Australian Academic \& Research Libraries, 47(4),

239-244. https://doi.org/10.1080/00048623.2016 .1248236

Campbell, S. (2008). Defining information literacy in the 21ist century. In J. Lau (Ed.), IFLA publication 131 'information literacy: International perspective. The Netherlands: IFLA Publication. Retrieved from https:/ / scholar.google.co.id/scholar?ci tes $=6880616256290545419 \&$ \&as_sdt $=2005$ \&sciodt $=0,5 \& \mathrm{hl}=\mathrm{id}$

CILIP. (2018). CILIP definition of information literacy 2018. Retrieved from

https:/ /infolit.org.uk/ILdefinitionCILI P2018.pdf

Crook, B., Stephens, K. K., Pastorek, A. E., Mackert, M., \& Donovan, E. E. (2015). Sharing health information and influencing behavioral intentions: The role of health literacy, information overload, and the internet in the diffusion of healthy Heart Information.
Health Communication, 31(1), 60-71. https://doi.org/10.1080/10410236.2014 .936336

Deyrup, M. M. (2009). Information Literacy: Discipline-specific or core competency? Slavic \& East European Information Resources, 10(2-3), 185-199. https:/ / doi.org/10.1080/152288809030 19353

Erza, E. K., Yusup, P. M., \& Erwina, W. (2017). Komunikasi budaya masyarakat Pandai Sikek dalam melakukan transformasi pengetahuan lokal. Kajian Informasi \& Perpustakaan, 5(2), 141-154. https://doi.org/10.24198/jkip.v5i2.107 16

Esariti, L., Yuliastuti, N., \& Ratih, N. K. (2017). Riverine settlement adaptation characteristic in Mentaya River, East Kotawaringin Regency, Kalimantan Province. In IOP Conference Series: Earth and Environmental Science (pp. 1-9). Surakarta: IOP Publishing. Retrieved from

https:/ /iopscience.iop.org/article/10.1 088/1755-1315/123/1/012039/pdf

Fatimah, S., Yunita, Gunardi, \& Yosini D. (2018). Masyarakat informasi pada sektor pertanian: Kasus petani cabai Desa Genteng, Kabupaten Sumedang, Jawa Barat. Pax Humana: Jurnal Humaniora Yayasan Bina Darma, 5(1), 716. Retrieved from http:/ / www.jurnalilmiahpaxhumana.org/index.php/PH/article /view/136/pdf

Ismaini, S. (2013). Hubungan antara solidaritas dengan agresivitas pada anggota TNI-AD (Skripsi). Universitas Muhammadiyah Surakarta, Solo. Retrieved from http:/ / eprints.ums.ac.id/26691/10/02. _Naskah_Publikasi.pdf

Jiang, Q., \& Ke, G. (2018). Information sharing and bullwhip effect in smart 
destination network system. Ad Hoc Networks, $\quad 87(6)$, 17-25. https://doi.org/10.1016/j.adhoc.2018.0 7.006

Khairani, C. (2014). Pendorong interaksi sosial masyarakat Aceh dalam warung kopi. Lentera, 14(10), 50-57. Retrieved from

http://jurnal.umuslim.ac.id/index.php /LTR1/article/view/277/294

Kim, J. H. (2010). Does sharing information before a clinical skills examination impact student performance? Medical Teacher, 32(9), 747-753. https://doi.org/10.3109/014215910036 90338

Koentjaraningrat. (2009). Pengantar antropologi. Jakarta: Rineka Cipta.

Kuncoro, W. (2013). Eksistensi ruang publik di media cetak: Studi kasus Jawa Pos, Surya, dan Surabaya Post. Jurnal Komunikasi Islam, 3(2), 226-249. https://doi.org/10.15642/jki.2013.3.2.2 26-249

Lau, J. (2006). Guidelines on information literacy for lifelong learning. Retrieved from

https:/ / scholar.google.co.id/scholar?ci tes $=11062436245009158816 \&$ as_sdt $=200$ $5 \&$ sciodt $=0,5 \& \mathrm{hl}=\mathrm{id}$

Lazuardi, F. H. (2016). Literasi informasi pada mahasiswa melalui budaya 'nongkrong': Studi pada kantin "CL" Universitas Brawijaya Malang (Skripsi). Universitas Brawijaya, Malang.

Luthfia, A. R. (2013). Menilik urgensi desa di era otonomi daerah. Jurnal of Rural and Development, 4(2), 135-143. Retrieved from https:/ /jurnal.uns.ac.id/rural-anddevelopment/article/view/1858/1760

Miles, M. B., Huberman, A. M., \& Saldana, J. (2014). Qualitative data analysis: A methods sourcebook (3rd ed.). USA: Sage
Publication Inc.

Mittal, S., Padmaja, S. S., \& Ajay, A. (2018). Agricultural information and knowledge network in rural India: A case of Bihar. The Journal of Agricultural Education and Extension: Competence for Rural Innovation and Transformation, 24(5), $1-26$. https:/ / doi.org/10.1080/1389224X.201 8.1491871

Myerson, R. (2017). Village communities and global development. In IEA 2017 World Congress. Mexico: The International Economic Association (IEA). Retrieved from http:/ /home.uchicago.edu/ rmyerson / research/villages.pdf

Nifadkar, S. S., Wu, W., \& Gu, Q. (2018). Supervisors' work-related and nonwork information sharing: Integrating research on information sharing, information seeking, and trust using self-disclosure theory. Personnel Psychology, 72(2), 1-44. https://doi.org/10.1111/peps.12305

Pels, J. (2009). Knowledge sharing, information management, communication and IT within WASHCost. Knowledge Management for Development Journal, 5(3), 215-228. https://doi.org/10.1080/194741909034 51157

Schneider, T., Eli, K., McLennan, A., Dolan, C., Lezaun, J., \& Ulijaszek, S. (2017). Governance by campaign: The coconstitution of food issues, publics and expertise through new information and communication technologies. Information, Communication $\mathcal{E}$ Society, 22(2), 1-21. https:/ / doi.org/10.1080/1369118X.201 7.1363264

Sokoloff, J. (2012). Information literacy in the workplace: Employer expectations. 
Journal of Business \& Finance Librarianship, 17(1), 1-17. https://doi.org/10.1080/08963568.2011 .603989

Taeko, T. (2013). The complexity of literacy in Kenya: Narrative analysis of Maasai women's experiences. Compare: A Journal of Comparative and International Education, 44(5), 826-844. https://doi.org/10.1080/03057925.2013 .806163

Tayebi, S. M., Manesh, S. R., Khalili, M., \& Sadi-Nezhad, S. (2019). The role of information systems in communication through social media. International Journal of Data and Network Science, 3(3), 245-268.

https://doi.org/10.5267/j.ijdns.2019.2. 002

Toepfer, S., Kuhlmann, U., Kansiime, M., Onyango, D. O., Davis, T., Cameron, K., \& Day, R. (2018). Communication, information sharing, and advisory services to raise awareness for fall armyworm detection and area wide management by farmers. Journal of Plant Diseases and Protection, 126(2), 103-106.

https://doi.org/10.1007/s41348-0180202-4

Weiner, S. A., Jackman, L. W., \& Prause, E. (2013). Strategizing for public policy: The information literacy state proclamation project. Public Services Quarterly, 9(4), 284-299. https://doi.org/10.1080/15228959.2013 .842400

Widayanti, S. (2016). Etika lingkungan dalam ungkapan budaya Jawa: Relevansinya dengan pengelolaan lingkungan hidup di Indonesia (Disertasi). Universitas Gadjah Mada, Yogyakarta.

Zhang, W., Sun, S. L., Jiang, Y., \& Zhang, W. (2019). Openness to experience and team creativity: Effects of knowledge sharing and transformational leadership. Creativity Research Journal, 31(1), https://doi.org/10.1080/10400419.2019 .1577649 